\section{Pengaruh Electronic Word Of Mouth Dan Promosi Media Sosial Terhadap Minat Beli Pada Produk Fashion Eiger}

\author{
Bona Aripin Sinaga dan Sulistiono \\ Program Studi Manajemen, Institut Bisnis dan Informatika Kesatuan \\ E-Mail: angga.sulistiono@ibik.ac.id
}

\begin{abstract}
Eiger as a fashion brand and outdoor equipment often promotes social media through advertisements on social media, but the advertisement is sometimes not well targeted, so it is seen by many people who do not like to do outdoor activities, which makes the promotion by Eiger ineffective. This study aims to 1). Knowing the effect of eWOM on buying interest in Eiger fashion products in Bogor, 2). Knowing the effect of promoting social media on buying interest in Eiger fashion products in Bogor, and 3). To determine the effect of electronic word of mouth and social media promotion on buying interest in Eiger fashion products in the city of Bogor. This research uses a quantitative approach involving 100 respondents. Primary data collection using a questionnaire and secondary data collection using literature study. Hypothesis testing in this study uses multiple linear regression analysis with a significance value $\square=5 \%$ using SPSS 22 analysis tools. The results of the study show that simultaneously electronic variable word of mouth and social media promotion variables have positive and significant influence on buying interest. Partially the electronic word of mouth variable has a positive and significant influence on buying interest, as well as the variable of social media promotion which has a significant and positive influence on buying interest.
\end{abstract}

Keywords: electronic word of mouth, buying interest, social media promotion
Buying Intention

and Promotional

Mix
Submitted: MARET 2020

Accepted: JULI 2020

\begin{abstract}
ABSTRAK
Eiger sebagai brand fashion dan perlengkapan outdoor sering melakukan promosi media sosial melalui iklan di media sosial, namun iklan tersebut terkadang kurang tepat sasaran, sehingga banyak dilihat oleh masyarakat yang kurang suka melakukan aktivitas outdoor, hal ini menjadikan promosi yang dilakukan Eiger tidak efektif. Penelitian ini bertujuan untuk 1). Mengetahui pengaruh eWOM terhadap minat beli produk fashion Eiger di kota Bogor, 2). Mengetahui pengaruh promosi media sosial terhadap minat beli produk fashion Eiger di kota Bogor, dan 3). Untuk mengetahui pengaruh electronic word of mouth dan promosi media sosial terhadap minat beli pada produk fashion Eiger di kota Bogor. Penelitian ini menggunakan pendekatan kuantitatif dengan melibatkan 100 responden. Pengumpulan data primer menggunakan kuesioner dan pengumpulan data sekunder menggunakan studi pustaka. Pengujian hipotesis dalam penelitian ini menggunakan analisis regresi linier berganda dengan nilai signifikansi $\alpha=5 \%$ menggunakan alat analisis SPSS 22. Hasil penelitian menunjukkan bahwa secara simultan variabel electronic word of mouth dan variabel promosi media sosial berpengaruh positif dan signifikan terhadap minat beli. Secara parsial variabel electronic word of mouth berpengaruh positif dan signifikan terhadap minat beli, begitu juga dengan variabel promosi media sosial memiliki pengaruh yang signifikan dan positif terhadap minat beli.
\end{abstract}

Kata Kunci: electronic word of mouth, minat beli, promosi media sosial

\section{JIMKES}

$$
\begin{array}{r}
\text { Jurnal Ilmiah Manajemen } \\
\text { Kesatuan } \\
\text { Vol. } 8 \text { No. 2, 2020 } \\
\text { pp. 79-94 } \\
\text { IBI Kesatuan } \\
\text { ISSN 2337 - 7860 } \\
\text { E-ISSN 2721 - 169X }
\end{array}
$$


Customer Buying

Decision and

Promotional Mix

\section{PENDAHULUAN}

Pada zaman sekarang, kemajuan teknologi dan globalisasi membuat setiap elemen dalam kegiatan ekonomi mengalami pergeseran dalam setiap aktivitasnya. Konsumen menginginkan pola pemenuhan kebutuhan yang efektif dan efisien dan produsen menghasilkan produk-produk inovasi yang selama ini mungkin tidak pernah ada dalam benak orang lain. Kemajuan teknologi terlihat seperti meningkatnya jumlah telepon seluler, meningkatnya penggunaan internet dan munculnya bisnis yang selama ini tidak diperhitungkan dan tiba-tiba merajai pasar seperti yahoo, Amazon.com, google atau e-bay. Setiap orang memiliki notebook atau netbook, serta munculnya smartphone yang dilengkapi oleh internet acces, layanan e-mail, facebook, twitter dan sebagainya. Perkembangan ilmu pengetahuan dan teknologi semakin memperluas perdagangan bebas seolah-olah perdagangan menjadi tanpa batas ruang dan waktu, hal ini menyebabkan semakin tinggi pula persaingan yang harus dihadapi oleh semua pihak terutama pihak perusahaan selaku produsen, Perusahan-perusahaan menentukan strategi pemasaran agar menjadi pilihan konsumen.

Pemahaman akan keadaan pasar dan perumusan strategi pasar yang tepat akan memenangkan persaingan, salah satu strategi yang dilakuakan adalah memanfaatkan promosi yang merupakan salah satu dari unsur-unsur bauran pemasaran yaitu perantara antara produsen dengan konsumen dalam berkomunikasi. Seiring dengan pesatnya perkembangan teknologi, perusahaan dituntut untuk dapat memiliki strategi terbaik untuk dapat menarik pelanggan supaya mau membeli produk mereka. Selain itu, para pelanggan saat ini adalah pelanggan yang cerdas dan kritis. Konsumen dapat mengakses berbagai informasi sebelum memutuskan untuk membeli suatu produk dengan mencari informasi lewat berbagai cara, misalnya melalui internet, bertanya kepada teman, dan tak mudah percaya pada apa yang diucapkan perusahaan atau sales representative yang melakukan promosi.

Promosi yang dilakukan perusahaan juga telah mengalami pergeseran, dimana banyak perusahaan yang beralih dari promosi melalui media cetak dan elektronik beralih ke promosi melalui internet yang salah satunya adalah media sosial. Hadirnya media sosial seperti facebook, twitter, YouTube sebagai media promosi karena media sosial menjadi porsi terbesar bagi konsumen menghabiskan waktunya secara online. Media sosial menjadi tempat yang tepat untuk mempromosikan produk ke konsumen. Gambar 1.1 ditunjukkan mengenai pemanfaatan media sosial sebagai media promosi sebagai berikut:

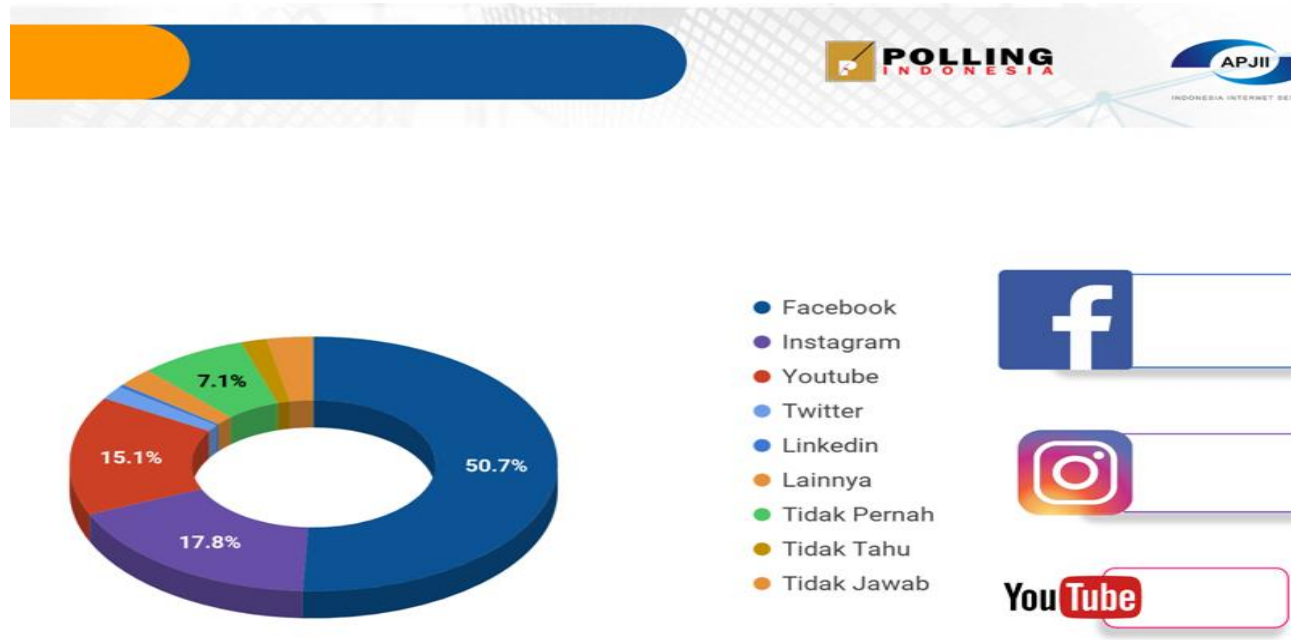

Gambar 1. Penggunaan media sosial

Sumber:Asosiasi Penyelenggara Jasa Internet Indonesia (APJII) 2018 
Berdasarkan Gambar 1. dapat dilihat bahwa jejaring sosial sebagai media sosial teratas yang digunakan perusahaan sebagai media promosi sehingga perusahaan berlombalomba meggunakan media sosial untuk mempromosikan produknya seperti Facebok, Instagram, dan Youtube Meningkatnya penggunaan internet dan media sosial juga menimbulkan fenomena yang dalam istilah pemasaran sering disebut eWOM Electronic Word Of Mouth, eWOM berperan besar dalam pengaruhnya pada pengambilan keputusan pembelian konsumen dan dalam pembentukan pola perilaku konsumen (Jalilvand, 2012). eWOM dirasa lebih efektif karena informasinya yang lebih reliabel, jenis komunikasi dengan pesan non-commercial ini memiliki tingkat persuasif yang lebih tinggi dengan kepercayaan dan kredibilitas yang tinggi pula (Jalilvand, 2012). Sebagian besar orang cenderung lebih percaya pada pemasaran dari mulut ke mulut dibanding metode promosi apapun yang sifatnya lebih formal. Orang yang menerima rekomendasi berdasarkan komunikasi dari mulut ke mulut cenderung lebih yakin bahwa sang pemberi rekomendasi berbicara jujur dan tidak ditunggangi motif tersembunyi (Christy, 2010).

Persepsi yang positif tentang suatu produk atau jasa akan merangsang timbulnya minat konsumen untuk membeli yang pada akhirnya ditentukan oleh perilaku pembelian. Menurut Arwiedya (2011) dalam media promosi yang berpengaruh terhadap keputusan seseorang dalam pembelian salah satunya ialah onlineword of mouth dengan mengatakan bahwa onlineword of mouth adalah komunikasi interpersonal dengan media online antara dua bahkan lebih individu seperti anggota kelompok referensi atau konsumen dan tenaga penjual dimana semua orang mempunyai pengaruh atas keputusan pembelian. Menurut Ward dan Ostrom dalam Zhang (2010) internet saat ini telah sangat diberdayakan konsumen untuk melakukan berbagi informasi yang saat ini dapat dengan mudah diakses dan sebagian besar konsumen dapat memberitahukan pengalamannya melalui internet dan mempengaruhi konsumen lainnya melalui eWOM.

Eiger merupakan salah satu merek yang dilahirkan di bawah bendera PT. Eigerindo Multi Produk Industri pada tahun 1990 yang bergerak dalam bidang bisnis perlengkapan petualangan. Eiger adalah salah satu merek perlengkapan outdoor yang cukup dikenal oleh para petualang alam bebas di tanah air. Merek Eiger terkenal dengan berbagai macam produk perlengkapan outdoor-nya, terutama produk tas ransel (daypack). Tas ransel merupakan salah satu produk unggulan EIGER yang sampai saat ini merupakan market leader di Indonesia. Kualitas produk Eiger dapat dikatakan serata dengan produk outdoor di luar negeri yang terkenal sehingga banyak yang mempersepsikan bahwa kualitas Eiger sudah diakui sehingga tak jarang jika banyak konsumen yang membicarakan produk Eiger dan menjadi trend dikalangan pecinta alam. Dengan harga yang relatif berdasarkan fungsi dan juga kualitasnya membuat Eiger menjadi produk yang dipertimbangkan oleh setiap konsumen dalam melakukan keputusan pembelian. Kualitas produk yang selalu dijaga dan diperbaharui serta mengikuti selera dan trend pasar menjadi andalan Eiger untuk tetap bertahan dalam persaingan industri perlengkapan outdoor masa kini, kontrol yang ketat terhadap produksi serta dengan memberikan pelayanan yang maksimal kepada pelanggan adalah cara yang dilakukan agar para pelanggan Eiger tidak berpaling ke produk atau merek lain.

Rimayanti (2018) dalam penelitiannya mengenai pengaruh kualitas produk dan citra merek terhadap loyalitas pelanggan pada tas Eiger di Samarinda menunjukkan bahwa kualitas produk dan citra merek berpengaruh positif dan signifikan secara simultan terhadap loyalitas pelanggan. Kinerja, daya tahan, fitur produk, kesan kualitas dan kesesuaian produk masih menjadi daya tarik tersendiri bagi pelanggan setia produk Eiger. Sementara itu Kholiq (2019) dalam analisis SWOT terhadap store Eiger di Kaliurang Yogyakarta menyampaikan bahwa kekuatan PT. Eigerindo Multi Produk Store di Jalan Kaliurang Yogyakarta adalah segmentasi, targeting, dan positioning jelas, banyak inovasi produk, produk berkualitas, brand image terkenal, dan store yang banyak. Kelemahan pada store ini adalah harga lebih mahal, sumberdaya manusia yang kurang kompeten, dan pendistribusian yang terlambat. Peluang yang dimiliki oleh store adalah masih banyak orang yang suka dengan petualangan, produk pesaing kurang lengkap, segmen
Customer Buying

Decision and

Promotional Mix 
Customer Buying

Decision and

Promotional Mix

pasar besar, sedangkan ancaman yang dihadapi store adalah masuknya produsen dari Tiongkok, produk palsu dengan merek Eiger. Untuk strategi yang dapat diterapkan oleh PT Eigerindo Multi Produk store jalan Kaliurang yaitu mempertahankan posisi kompetitif pasar yang kuat, menjaga kualitas produk, meningkatkan kualitas pelayanan. Sedangkan Heruwansyah (2019) menyebutkan bahwa kualitas produk, promosi penjualan dan lokasi gerai secara bersama-sama memiliki pengaruh yang positif dan signifikan terhadap keputusan pembelian konsumen Eiger di Bogor. Kualitas produk Eiger masih berada diposisi atas brand perlengkapan outdoor dibandingkan dengan brand lain dengan produk sejenis, promosi penjualan masih harus ditingkatkan jika ingin pelanggan tidak lari ke produk lain, sementara lokasi gerai perlu diperhatikan jumlah gerai yang ada disetiap kota apakah sudah sesuai dengan kebutuhan dan mudah dijangkau oleh pelanggan. Masih banyak pelanggan Eiger yang tidak puas terhadap kualitas tas Eiger, konsumen menyampaikan bahwa kualitas yang dijual Eiger tidak sesuai dengan harga yang mereka beli, dan promosi yang dilakukan Eiger sangat jarang dilakukan jika disbanding dengan kompetitornya.

Namiramiyah melakukan penelitian tentang akun facebook sebagai sarana marketing public relationship Eigerindo Multi Produk Industri dengan hasil penelitian menunjukkan bahwa PT. Eigerindo Multi Produk Industri menggunakan media sosial Facebook dalam kegiatan Marketing Public Relations. Dengan menggunakan Push Strategy (strategi mendorong) media sosial Facebook dapat mendorong meningkatkan pembelian produk dan mendorong masyarakat mengikuti acara atau kegiatan yang diselenggarakan Eiger. Pull Strategy (strategi menarik) media sosial Facebook dapat menarik masyarakat mengikuti acara atau kegiatan dengan cara memberikan informasi adanya doorprize atau discount dalam media sosial Facebook. Pass strategy (strategi mempengaruhi) media sosial Facebook memberikan informasi acara atau kegiatan sosial yaitu seperti membersihkan sungai bersama dan acara lain yang berhubungan langsung dengan masyarakat. Kendala yang dihadapi Eiger yaitu kurangnya tenaga (karyawan) dalam memanfaatkan media sosial Facebook sebagai alat Marketing Public Relations. Sedangkan Setiawan dan Rachmawati (2019) melakukan penelitian dengan tujuan untuk mengkaji penggunaan content marketing sebagai strategi pemasaran Eiger Adventure di Instagram. Hasil penelitiannya menunjukkan bahwa alasan penggunaan content marketing Eiger di Instragram yang low budget-high impact dan sifatnya yang soft selling. Sedangkan Rofian (2016) melakukan penelitian tentang pengaruh word of mouth, persepsi kualitas dan harga terhadap keputusan pembelian produk Eiger dengan hasil penelitian menunjukkan bahwa ketiga variabel yaitu word of mouth, persepsi kualitas dan harga berpengaruh positif dan signifikan terhadap keputusan pembelian.

Electronic word of mouth (eWOM) merupakan bentuk terbaru dari WOM. Word of Mouth (WOM)adalah keseluruhan komunikasi dari orang ke orang mengenai suatu produk, jasa atau perusahaan tertentu pada suatu waktu (Rosen, 2000:7). Word of Mouth (WOM) adalah kegiatan promosi yang dilakukan oleh konsumen yang menawarkan produk secara sukarela, dimana mereka menceritakan produk dan menyarankan orang lain untuk mengkonsumsi atau menggunakan produk tersebut (Ekotama, 2009: 17). Word of Mouth (WOM) adalah proses dimana informasi yang didapatkan oleh seseorang tentang suatu produk baik dari interaksi sosial maupun dari pengalaman konsumsi yang diteruskan kepada orang lain (Ristiyanti, 2005:144). Dari penjelasan di atas dapat dilihat bahwa WOM merupakan cikal bakal terbentuknya eWOM. Dengan berkembangnya teknologi komunikasi, konsep WOM pun mengalami evolusi. Apabila dulu, komunikasi WOM hanya disampaikan oleh sumber informal yang dikenal baik oleh penerima pesan, saat ini komunikasi informal yang mempengaruhi pembelian konsumen dapat disampaikan melalui internet yang memberikan kemudahan bagi masyarakat untuk berkomunikasi langsung dengan orang dari berbagai belahan dunia tanpa harus bertatap muka. Bersamaan dengan munculnya komunitas virtual dalam jejaring sosial di internet, maka muncul pula istilah electronic word of mouth (eWOM). Word of Mouth Online (eWOM) adalah proses word of mouth dengan menggunakan media internet. 
Melalui aktivitas eWOM, konsumen akan mendapatkan tingkat transparansi pasar yang tinggi, dengan kata lain konsumen memiliki peran aktif yang lebih tinggi dalam siklus rantai nilai sehingga konsumen mampu mempengaruhi produk dan harga berdasarkan preferensi individu (Park dan Kim, 2008). Perbedaan antara WOM dan eWOM dapat dibedakan berdasarkan pada media digunakan. Penggunaan WOM tradisional biasanya bersifat face to face (tatap muka), sedangkan penggunaan eWOM biasanya bersifat secara online melalui cyberspace. Seiring berkembangnya kemajuan teknologi, tempat fisik dimana word of mouth terjadi, telah berubah dari face to face ke cyberspace. Pengukuran eWOM dapat dilakukan dengan menggunakan dimensi eWOM.

Menurut Goyette et al. (2010) dijelaskan bahwa terdapat indikator-indikator yang dapat digunakan untuk mengukur electronic word of mouth, yaitu:

1. Intensity. Intensitas dalam electronic word of mouth adalah banyaknya pendapat yang ditulis oleh konsumen dalam sebuah jejaring sosial. Komponen dari intensitas adalah:

a. Frekuensi mengakses informasi dari situs jejaring sosial

b. Frekuensi interaksi dengan pengguna situs jejaring sosial

c. Banyaknya ulasan yang ditulis oleh pengguna situs jejaring sosial.

2. Positive Valence, adalah pendapat konsumen yang positif mengenai produk, jasa, dan brand. Komponen dari positif valence meliputi:

a. Komentar positif dari pengguna situs jejaring sosial

b. Rekomendasi dari pengguna situs jejaring sosial

3. Negative Valence, adalah pendapat konsumen yang negatif mengenai produk, jasa, dan brand. Komponen dari negatif valence adalah komentar negatif dari pengguna situs jejaring sosial.

4. Content. Adalah isi informasi dari situs jejaring sosial berkaitan dengan produk dan jasa. Komponen dari konten meliputi:

a. Informasi variasi makanan dan minuman

b. Informasi kualitas (jasa, tekstur, suhu)

c. Informasi harga.

Promosi menjadi salah satu bagian yang menjadikan organisasi pemasar berhasil. Promosi yang disebut juga alat mengkomunikasikan produk telah mengalami perkembangan dimana pemasar lebih mudah dan lebih cepat dalam mempromosikan produknya. Hal ini disebabkan munculnya berbagai media baru yang dapat dimanfaatkan untuk menjangkau konsumen lebih cepat dan luas. Secara klasik promosi adalah semua kegiatan yang dilakukan perusahaan untuk mengkomunikasikan dan mempromosikan produknya ke target pasar (Kotler, 2004). Promosi sebagai unsur utama dalam kampanye pemasaran merupakan kumpulan alat-alat yang insentif yang sebagian besar berjangka pendek, yang dirancang untuk merangsang pembelian produk atau jasa tertentu dengan lebih cepat dan lebih besar oleh konsumen atau pedagang (Kotler dan Keller, 2007). Penggunaan media sosial digunakan oleh masyarakat dalam melakukan banyak aktivitas mulai dari entertainment, melakukan bisnis, mencari info atau aktivitas lainnya. Pengguna internet aktif di Indonesia per Januari 2016 mencapai 88.1 juta orang dan 79 juta di antaranya merupakan pengguna media sosial yang aktif (Balea, 2016). Instagram sebagai salah satu media sosial populer di Indonesia berada di peringkat kedelapan dengan pengguna mencapai $10 \%$. Berdasarkan sumber e-marketer.com (2017), penggunaan instagram di Indonesia bagi pengguna dengan usia 16-35 tahun, melakukan posting fotofoto saat travelling mencapai $48.4 \%$ (peringkat ketiga).

Di Indonesia, jumlah pengguna instagram aktif mencapai 22 juta orang. Adapun dengan persebaran demografi pengguna instagram 18-29 tahun memiliki penggunaan terbesar yaitu $83 \%$. Namun $18 \%$ dari mereka yang berumur $30-49$ tahun dan $6 \%$ dari umur 50-64 tahun juga menggunakan instagram. Berdasarkan data tersebut, maka instagram merupakan salah satu media yang potensial untuk digunakan sebagai media promosi.

Menurut Charity (2011) dalam jurnalnya mengatakan bahwa efektivitas Social Media Marketing (SMM) sangat dipengaruhi oleh beberapa aspek yaitu: Kualitas konten;
Customer Buying

Decision and

Promotional Mix 
Customer Buying

Decision and

Promotional Mix
Membangun kepercayaan (hubungan); Keterlibatan ; Integrasi dengan platform media lainnya.

Minat beli merupakan kecenderungan konsumen untuk membeli suatu merek atau mengambil tindakan yang berhubungan dengan pembelian yang diukur dengan tingkat kemungkinan konsumen melakukan pembelian (Assael, 2001). Minat beli konsumen merupakan kegiatan-kegiatan individu yang secara langsung terlibat dalam mendapatkan dan menggunakan barang dan jasa termasuk di dalamnya proses pengambilan keputusan pada persiapan dan penentuan kegiatankegiatan tersebut (Swastha dan Handoko, 2000). Artinya bahwa minat beli konsumen merupakan tindakan-tindakan dan hubungan sosial yang dilakukan oleh konsumen perorangan, kelompok maupun organisasi untuk menilai, memperoleh dan menggunakan barang-barang serta jasa melalui proses pertukaran atau pembelian yang diawali dengan proses pengambilan keputusan yang menentukan tindakan-tindakan tersebut. Schiffman dan Kanuk (2007), menjelaskan bahwa pengaruh eksternal, kesadaran akan kebutuhan, pengenalan produk dan evaluasi alternatif adalah hal yang dapat menimbulkan minat beli konsumen. Pengaruh eksternal ini terdiri dari faktor sosial, usaha pemasaran, dan faktor sosial budaya. Menurut Kotler dan Keller (2003), customer buying decision - all their experience in learning, choosing, using, even disposing of a product.

Menurut Anwar (2007) faktor-faktor yang mempengaruhi konsumen melakukan pembelian terhadap suatu produk adalah tahap keinginan (interest) lalu tahap kehendak (awarnes) yang kuat untuk menikmati jasa tersebut. Menurut Ferdinand (2002) minat beli dapat diidentifikasi melalui indikator - indikator sebagai berikut:

1. Minat transaksional

Yaitu kecenderungan seseorang untuk membeli produk. Hal ini bermaksud yakni konsumen telah memiliki minat untuk melakukan pembelian suatu produk tertentu yang ia inginkan.

2. Minat referensial

Yaitu kecenderungan seseorang untuk mereferensikan produk kepada orang lain. Hal ini bermaksud yakni seorang konsumen yang telah memiliki minat untuk membeli akan menyarankan orang terdekatnya untuk juga melakukan pembelian produk yang sama.

3. Minat preferensial

Yaitu minat yang menggambarkan perilaku seseorang yang memiliki preferensi utama pada produk tersebut. Preferensi ini hanya dapat diganti jika terjadi sesuatu dengan produk preferensinya.

4. Minat eksploratif

Minat ini menggambarkan perilaku seseorang yang selalu mencari informasi mengenai produk yang diminatinya dan mencari informasi untuk mendukung sifatsifat positif dari produk tersebut.

Adapun maksud dan tujuan penelitian ini adalah sebagai berikut:

1. Untuk mengetahui seberapa besar pengaruh eWOM terhadap minat beli produk fashion Eiger di Kota Bogor

2. Untuk mengetahui seberapa besar pengaruh promosi melalui media sosial tehadap minat beli produk fashion Eiger di Kota Bogor

3. Untuk mengetahui secara bersama-sama seberapa besar pengaruh Electronic Word Of Mouth dan promosi media sosial terhadap minat beli pada produk fashion Eiger di Kota Bogor

\section{METODE PENELITIAN}

Penelitian dilakukan di Kota Bogor dengan lamanya penelitian selama 3 Bulan dari bulan April 2020 Hingga Juli 2020. Jenis penelitian ini adalah penelitian asosiatif yaitu suatu jenis penelitian yang melihat hubungan atau pengaruh suatu variabel terhadap variabel lain serta melakukan pengujian hipotesis dengan menggunakan data-data yang 
terukur dan alat analisis. Dari penelitian ini akan diperoleh kesimpulan yang dapat di generalisasikan. Data primer dalam penelitian ini diperoleh dengan cara melakukan penyebaran kuisioner kepada responden Mahasiswa/i STIE KESATUAN. Metode yang digunakan untuk mengumpulkan data primer yaitu melalui wawancara, penyebaran kuisioner, dan observasi secara langsung kepada individu atau perseorangan dengan penyataan yang sesuai dengan indikator variabel Pengaruh Electronic word of mouth (X1), Pengaruh Promosi Media Sosial (X2), terhadap Minat Beli (Y). Populasi yang digunakan dalam penelitian ini adalah semua orang yang pernah membeli produk Eiger dan tinggal di kota Bogor. Berdasarkan hasil survey yang dilakukan oleh peneliti, didapat data bahwa jumlah pengunjung yang datang ke store Eiger di Sukasari sebanyak kurang lebih 1293 setiap bulannya. Dengan menggunakan rumus slovin diperoleh ukuran sampel sebanyak 100 orang.

Metode Analisis Data menggunakan Analisis regresi Berganda dengan sebelumnya melakukukan uji kualitas data secara bertahap mulai dari uji validitas dan reliabilitas lalu dilanjutkan dengan uji asumsi klasik yang meliputi uji normalitas, uji multikoliniearitas dan uji heteroskedastisitas. Hasil uji kualits data menunjukkan bahwa data telah memenuhi syarat untuk dilakukan uji regresi berganda.

Hipotesis yang diajukan dalam penelitian ini adalah sebagai berikut :

1. Hipotesis pertama $(\mathrm{H} 1)$ : Electronic word of mouth $\left(\mathrm{X}_{1}\right)$ berpengaruh positif terhadap Minat Beli (Y)

2. Hipotesis kedua (H2): Promosi Media Sosial $\left(\mathrm{X}_{2}\right)$ berpengaruh positif terhadap Minat $\operatorname{Beli}(\mathrm{Y})$

3. Hipotesis ketiga (H3): Electronic word of mouth $\left(\mathrm{X}_{1}\right)$, Promosi Media Sosial $\left(\mathrm{X}_{2}\right)$ secara bersama-sama berpengaruh positif terhadap Minat Beli (Y)

\section{HASIL DAN PEMBAHASAN \\ Profil Responden}

Penelitian ini dilakukan dengan menyebar kuesioner kepada 100 responden secara acak. Karakteristik responden dalam penelitian ini meliputi jenis kelamin dan pendapatan per bulan. Hasil analisis data untuk karakteristik responden sebagaimana dijelaskan sebagai berikut:

Tabel 1 Distribusi Responden Berdasarkan Karakteristik Individu

\begin{tabular}{lcc}
\multicolumn{1}{c}{ Karakteristik } & Frekuensi & Persen (\%) \\
\hline JENIS KELAMIN & 38 & $38 \%$ \\
Laki-laki & 62 & $62 \%$ \\
Perempuan & & \\
PENGHASILAN & 39 & $39 \%$ \\
< Rp. 3.500.000 & 43 & $43 \%$ \\
Rp. 3.500.000 - Rp. 5.000.000 & 16 & $16 \%$ \\
Rp. 5.000.000 - Rp. 7.000 .000 & 2 & $2 \%$ \\
> Rp. 10.000 .000 & &
\end{tabular}

Sumber : Data Primer Output SPSS, 2020.

\section{Analisis Persepsi Responden}

Variabel electronic word of mouth (x1) terdiri dari tiga komponen pernyataan, diantaranya: Electronic word of mouth pada Produk Eiger memiliki Frekuensi mengakses Informasi dan Media Sosial yang tepat (x11), Electronic word of mouth pada Produk Eiger memiliki Frekuensi Interaksi dengan Pengguna Media Sosial yang tepat (x12), dan Electronic word of mouth pada Produk Eiger Mempengaruhi Banyaknya ulasan yang ditulis oleh pengguna Media Sosial (x13).

Variabel promosi media sosial terdiri dari empat komponen diantaranya: kegiatan promosi media sosial yang dilakukan Eiger memiliki frekuensi promosi yang baik (x21), kegiatan promosi media sosial yang dilakukan Eiger memiliki kualitas promosi yang baik (x22), kegiatan promosi media sosial yang dilakukan Eiger memiliki kuantitas promosi
Customer Buying

Decision and

Promotional Mix 
Customer Buying Decision and Promotional Mix

86 yang baik (x23), dan kegiatan promosi media sosial yang dilakukan eiger memiliki waktu promosi yang tepat $(\mathrm{x} 24)$.

Tabel 2 Persepsi Responden atas Indikator Variabel

\begin{tabular}{llll}
\hline No & Pertanyaan / Indikator & Rata-rata & Keterangan \\
\hline E-WOM & $\begin{array}{l}\text { Electronic Word of Mouth pada Produk Eiger } \\
\text { memiliki Frekuensi mengakses Informasi dan } \\
\text { Media Sosial yang tepat }\end{array}$ & 3.7 & Tinggi \\
\hline $\begin{array}{l}\text { Electronic Word of Mouth pada Produk Eiger } \\
\text { memiliki Frekuensi Interaksi dengan Pengguna } \\
\text { Media Sosial yang tepat }\end{array}$ & 3.71 & Tinggi \\
\hline $\begin{array}{l}\text { Electronic Word of Mouth pada Produk Eiger } \\
\text { Mempengaruhi Banyaknya ulasan yang ditulis } \\
\text { oleh pengguna Media Sosial }\end{array}$ & 3.78 & Tinggi \\
\hline PROMOSI MEDIA SOSIAL & $\begin{array}{l}\text { Kegiatan promosi media sosial yang dilakukan } \\
\text { Eiger memiliki frekuensi promosi yang baik }\end{array}$ & 3.76 & Tinggi \\
\hline 2 & $\begin{array}{l}\text { Kegiatan promosi media sosial yang dilakukan } \\
\text { Eiger memiliki kualitas promosi yang baik }\end{array}$ & 3.84 & Tinggi \\
\hline $3 \quad \begin{array}{l}\text { Kegiatan promosi media sosial yang dilakukan } \\
\text { Eiger memiliki kuantitas promosi yang baik }\end{array}$ & 3.84 & Tinggi \\
\hline 4 & $\begin{array}{l}\text { Kegiatan promosi media sosial yang dilakukan } \\
\text { eiger memiliki waktu promosi yang tepat }\end{array}$ & 3.79 & Tinggi \\
\hline
\end{tabular}

MINAT BELI Electronic word of mouth pada produk Eiger

1 menyebabkan saya perhatian dan berminat untuk melakukan transaksional

$3.83 \quad$ Tinggi

Promosi Media Sosial pada produk Eiger

2 menyebabkan saya perhatian dan berminat untuk melakukan transaksional

$3.83 \quad$ Tinggi

$$
\text { Electronic word of mouth pada produk Eiger }
$$

3 menyebabkan saya perhatian dan berminat untuk mereferensikan produk ini

3.69 Tinggi
Promosi Media Sosial pada produk Eiger

4 menyebabkan saya perhatian dan berminat untuk mereferensikan produk ini

5 Electronic word of mouth yang dilakukan Eiger

5 menyebabkan anda selalu memilih produk Eiger

$3.78 \quad$ Tinggi

6 Promosi Media Sosial yang dilakukan Eiger menyebabkan anda selalu memilih produk Eiger

Electronic word of mouth pada produk Eiger

7 menyebabkan saya terdorong untuk terus mencari Informasi tentang produk Eiger Promosi Media Sosial pada produk Eiger

8 menyebabkan saya terdorong untuk terus mencari Informasi tentang produk Eiger

Sumber: Data Primer Diolah, 2020

Variabel minat beli (Y) terdiri dari delapan komponen, yaitu: Electronic word of mouth pada produk Eiger menyebabkan saya perhatian dan berminat untuk melakukan transaksional (y1), Promosi Media Sosial pada produk Eiger menyebabkan saya perhatian dan berminat untuk melakukan transaksional (y2), Electronic word of mouth pada produk Eiger menyebabkan saya perhatian dan berminat untuk mereferensikan produk ini (y3), Promosi Media Sosial pada produk Eiger menyebabkan saya perhatian dan 
berminat untuk mereferensikan produk ini (y4), Electronic word of mouth yang dilakukan Eiger menyebabkan anda selalu memilih produk Eiger (y5), Promosi Media Sosial yang dilakukan Eiger menyebabkan anda selalu memilih produk Eiger (y6), Electronic word of mouth pada produk Eiger menyebabkan saya terdorong untuk terus mencari Informasi tentang produk Eiger (y7), dan Promosi Media Sosial pada produk Eiger menyebabkan saya terdorong untuk terus mencari Informasi tentang produk Eiger (y8).

\section{Analisis Regresi Berganda}

Analisis regresi berganda dilakukan untuk menguji hipotesis tentang pengaruh secara parsial dan secara simultan variabel independen terhadap variabel dependen. Hasil analisis regresi disajikan pada Tabel 3.

Tabel 3 Hasil Uji Regresi

\begin{tabular}{|c|c|c|c|c|c|c|}
\hline \multicolumn{7}{|c|}{ Coefficients $^{a}$} \\
\hline & & \multicolumn{2}{|c|}{$\begin{array}{l}\text { Unstandardized } \\
\text { Coefficients }\end{array}$} & \multirow{2}{*}{$\begin{array}{c}\text { Standardized } \\
\text { Coefficients }\end{array}$} & \multirow[b]{2}{*}{$\mathrm{t}$} & \multirow[b]{2}{*}{ Sig. } \\
\hline \multicolumn{2}{|c|}{ Model } & B & Std. Error & & & \\
\hline \multirow[t]{3}{*}{1} & (Constant) & 13.481 & 2.657 & & 5.074 & .000 \\
\hline & EWM Total & .439 & .206 & .199 & 2.125 & .036 \\
\hline & PMS_Total & .766 & .153 & .469 & 5.005 & .000 \\
\hline
\end{tabular}

a. Dependent Variable: Total minat beli

Tabel 3 menunjukkan output SPSS 22 statistic for windows dengan persamaan regresi linier berganda dirumuskan sebagai berikut:

$$
\mathrm{Y}=13.481+0.439 \mathrm{X} 1+0.766 \mathrm{X} 2+\mathrm{e}
$$

Hasil dari analisis dapat dijelaskan sebagai berikut:

1. Nilai konstanta persamaan diatas sebesar 13.481 angka tersebut menunjukkan bahwa jika X1 (electronic word of mouth) dan promosi media sosial (X2), konstan (tidak berubah), maka minat beli adalah sebesar 13.481.

2. X1 (electronic word of mouth) memiliki nilai koefisien sebesar 0.439 , artinya setiap kenaikan variabel electronic word of mouth sebesar 1 satuan maka minat beli akan mengalami kenaikan sebesar 0.439 .

3. X2 (promosi media sosial) memiliki nilai koefisien sebesar 0.766 , artinya setiap kenaikan variabel promosi media sosial sebesar 1 satuan maka minat beli akan mengalami kenaikan sebesar 0.766 .

\section{Koefisien Korelasi}

Koefisien korelasi merupakan suatu alat yang digunakan untuk mengukur tingkat keeratan hubungan antara variabel independen dengan variabel dependen. Nilai $\mathrm{R}$ akan berkisar antara $0-1$, semakin mendekati 1 hubungan antara variabel independen secara bersama-sama dengan variabel dependen semakin kuat.

Tabel 5. Hasil Uji Korelasi Variabel

\section{Model Summary}

\begin{tabular}{llrrr}
\hline Model & R & R Square & Adjusted R Square & Std. Error of the Estimate \\
\hline 1 & $.573^{\mathrm{a}}$ & .328 & .313 & 4.044 \\
\hline
\end{tabular}

a. Predictors: (Constant), PMS_Total, EWM Total

Nilai koefisien korelasi yang ditunjukkan pada Tabel 4.13 yaitu 0.573 , dengan demikian dapat dinyatakan bahwa ada hubungan yang positif antara variabel electronic word of mouth dan promosi media sosial dengan variabel minat beli yang dikategorikan Sedang

\section{Koefisien Determinasi $\left(\mathbf{R}^{2}\right)$}

Koefisien Determinasi $\left(\mathrm{R}^{2}\right)$ mengukur seberapa jauh kemampuan model dalam menerangkan variasi variabel dependen (Ghozali 2005). Nilai koefisien determinasi adalah antara 0 (nol) dan 1 (satu). Nilai $\mathrm{R}^{2}$ yang kecil berarti kemampuan variabelvariabel independen dalam menjelaskan variasi variabel dependen amat terbatas. Nilai

Customer Buying

Decision and

Promotional Mix 
Customer Buying Decision and Promotional Mix yang mendekati 1 berarti variabel-variabel independen memberikan hampir semua informasi yang dibutuhkan untuk memprediksi variasi variabel dependen (Ghozali 2005).

Pada Tabel 5 diketahui bahwa nilai koefisien determinasi ( $\mathrm{R}$ square) yaitu 0.328, artinya bahwa $32.8 \%$ variabel minat beli dapat dijelaskan oleh variabel electronic word of mouth dan promosi media sosial sedangkan sisanya yaitu $67.2 \%$ dijelaskan oleh sebabsebab yang lain diluar variabel yang belum diteliti. Sehingga dapat disimpulkan bahwa kemampuan variabel electronic word of mouth dan promosi media sosial dalam menjelaskan variasi variabel minat beli amat terbatas. Firman (2019) dalam penelitiannya menyimpulkan bahwa harga dan store atmosfer secara simultan berpengaruh signifikan terhadap keputusan pembelian di Eiger Store Komplek MMTC Medan.

\section{Uji Hipotesis}

Pengujian simultan merupakan pengujian secara bersama-sama variabel electronic word of mouth dan promosi media sosial terhadap minat beli. Jika nilai $\mathrm{F}_{\text {hitung }}>\mathrm{F}_{\text {tabel }}$ maka variabel bebas $(\mathrm{X})$ berpengaruh terhadap variabel terikat $(\mathrm{Y})$. Jika nilai $\mathrm{F}_{\text {hitung }}<\mathrm{F}_{\text {tabel }}$ maka variabel bebas $(\mathrm{X})$ tidak berpengaruh terhadap variabel terikat $(\mathrm{Y})$. Jika nilai sig. $<0.05$ maka variabel bebas $(\mathrm{X})$ berpengaruh signifikan terhadap variabel terikat $(\mathrm{Y})$. Jika nilai sig. $>0.05$ maka variabel bebas $(\mathrm{X})$ tidak berpengaruh signifikan terhadap variabel terikat (Y). Nilai $F_{\text {tabel }}$ dapat dilihat pada tabel statistik untuk signifikansi 0.05 dengan $\mathrm{dF} 1=(\mathrm{k}-$ 1) dan $\mathrm{dF} 2=(\mathrm{n}-\mathrm{k})$. Dimana $\mathrm{k}=$ jumlah variabel dan $\mathrm{n}=$ jumlah sampel pembentuk regresi. Jadi, $\mathrm{dF} 1=(3-1)=2$ dan $\mathrm{dF} 2=(91-3)=88$. Hasil diperoleh untuk $\mathrm{F}_{\text {tabel }}$ sebesar 3.10 .

Tabel 6 Hasil Uji f (Simultan)

\begin{tabular}{llccccc}
\hline \multicolumn{7}{c}{ ANOVA $^{\mathrm{b}}$} \\
\hline \multirow{2}{*}{ Model } & $\begin{array}{c}\text { Sum of } \\
\text { Squares }\end{array}$ & Df & Mean Square & F & Sig. \\
\hline \multirow{2}{*}{1} & Regression & 702.125 & 2 & 351.062 & 21.466 & $.000^{\mathrm{a}}$ \\
\cline { 2 - 7 } & Residual & 1439.172 & 88 & 16.354 & & \\
\cline { 2 - 7 } & Total & 2141.297 & 90 & & & \\
\hline
\end{tabular}

a. Predictors: (Constant), PMS_Total, EWM Total

b. Dependent Variable: Total minat beli

Hasil uji ANOVA atau uji $\mathrm{f}$ didapat nilai $\mathrm{F}_{\text {hitung }}$ sebesar 21.466, nilai ini lebih besar dari $F_{\text {tabel }}$ yaitu 3.10 atau $F_{\text {hitung }} 21.466>F_{\text {tabel }} 3.10$ dengan probabilitas 0.000 . Nilai probabilitas jauh lebih kecil dari 0.05 maka model regresi dapat digunakan untuk memprediksi minat beli atau dapat disimpulkan bahwa kedua variabel bebas electronic word of mouth dan promosi media sosial secara bersama-sama berpengaruh terhadap minat beli. Pada penelitian ini terdapat satu buah hipotesis utama yang akan diuji. Pengujian dilakukan dengan menggunakan nilai signifikansi yang terdapat pada tabel Anova hasil regresi. Batasan nilai signifikansi yang digunakan untuk menguji hipotesis adalah 0.05. Jika nilai

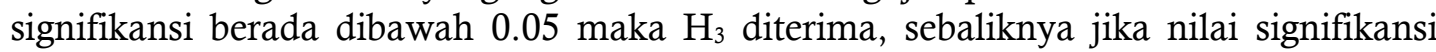
berada diatas 0.05 maka $\mathrm{H}_{3}$ ditolak. Hipotesis utama dalam penelitian ini adalah: Hipotesis ketiga (H3): Electronic word of mouth $\left(\mathrm{X}_{1}\right)$ dan promosi media sosial (X2) berpengaruh positif terhadap Minat Beli $(\mathrm{Y})$. Hasil analisis menunjukkan bahwa nilai signifikansi pada Tabel 4.15 lebih kecil dari 0.05 sehingga dapat disimpulkan bahwa hipotesis $\mathrm{H} 3$ diterima.

Untuk mengetahui bahwa electronic word of mouth dan promosi media sosial berpengaruh secara parsial terhadap minat beli, maka dilakukan uji t. Pengujian ini dilakukan dengan membandingkan $t_{\text {hitung }}$ dengan $t_{\text {tabel }}$ pada taraf nyata $\alpha=0.1$. Apabila hasil perhitungan $t_{\text {hitung }}$ lebih besar dari $t_{\text {tabel }}\left(t_{\text {hitung }}>t_{\text {tabel }}\right)$ atau probabilitas kesalahan lebih kecil dari 5\% (sig < 0.05) maka dapat dinyatakan bahwa X1 dan X2 berpengaruh terhadap $Y$. Nilai tabel dapat dilihat pada tabel statistik untuk signifikansi 0.05 dengan $\mathrm{df}=\mathrm{n}-\mathrm{k}$. Dimana $\mathrm{k}=$ jumlah variabel dan $\mathrm{n}=$ jumlah observasi/sampel pembentuk regresi. Jadi, df $=91-3=88$, maka nilai nilai $t_{\text {tabel }}$ sebesar 1.66. Adapun hasil uji t dapat dilihat pada 
Tabel 3 yang menunjukkan bahwa variabel electronic word of mouth (X1) memiliki thitung sebesar 2.125 dan nilai $t_{\text {tabel }}$ distribusi 5\% sebesar 1.66 sehingga dapat disimpulkan bahwa $t_{\text {hitung }}>t_{\text {tabel. }}$. Adapun nilai signifikansinya yaitu $0.036<0.05$ artinya variabel electronic word of mouth berpengaruh positif dan signifikan terhadap minat beli. Dengan hasil analisis ini maka dapat disimpulkan bahwa Hipotesis penelitian 1 (H1) (electronic word of mouth mempunyai pengaruh positif dan signifikan terhadap minat beli) dapat diterima.

Sedangkan untuk variabel promosi media sosial menunjukkan nilai t-hitung sebesar 5.005 dan nilai pada t-tabel 5\% sebesar 1.66 maka nilai t-hitung $>$ t-tabel. Adapun nilai signifikansi yaitu $0.000<0.05$. Hal ini berarti variabel promosi media sosial berpengaruh positif dan signifikan terhadap minat beli. Dengan demikian dapat disimpulkan bahwa Hipotesis Penelitian $2\left(\mathrm{H}_{2}\right)$ (Promosi media sosial mempunyai pengaruh positif dan signifikan terhadap minat beli) dapat diterima.

\section{Pembahasan}

Hasil analisis menunjukkan bahwa responden lebih banyak perempuan dengan ratarata penghasilan antara Rp. 3.500.000 hingga Rp. 5.000.000. Dalam penelitian ini terdapat tiga variabel yang diteliti yaitu electronic word of mouth (X1), promosi media sosial (X2) dan minat beli (Y). Variabel electronic word of mouth dan promosi media sosial merupakan variabel independen sedangkan variabel minat beli merupakan variabel dependen. Pengujian hipotesis antar variabel independen dan dependen dilakukan dengan menggunakan analisis SPSS 22. Berdasarkan hasil uji hipotesis maka disimpulkan bahwa electronic word of mouth dan promosi media sosial secara parsial berpengaruh positif dan signifikan terhadap minat beli fashion Eiger, sehingga hipotesis yang menyatakan electronic word of mouth berpengaruh positif dan signifikan terhadap minat beli (H1) dapat diterima. Demikian halnya dengan hipotesis promosi media sosial yang berpengaruh positif dan signifikan terhadap minat beli $(\mathrm{H} 2)$ dapat diterima. Hasil analisis secara simultan menunjukkan bahwa variabel electronic word of mouth dan promosi media sosial berpengaruh positif dan signifikan terhadap minat beli, sehingga hipotesis electronic word of mouth dan promosi media sosial berpengaruh positif dan signifikan terhadap minat beli fashion Eiger (H3) dapat diterima.

Pada uji validitas ini diketahui bahwa $\mathrm{n}$ adalah 100 dan $\alpha=5 \%$ sehingga $\mathrm{r}_{\text {tabel }}$ (5\%; $100-2)=0.195$. Setiap pernyataan dikatakan valid jika $r_{\text {hitung }}$ lebih besar dari $r_{\text {tabel }}$ sebesar 0.195 . Sehingga seluruh komponen pernyataan dapat diikutkan kembali dalam analisis selanjutnya. Uji Reliabilitas yang dilakukan memperoleh nilai Cronbach's Alpha sebesar 0.810 untuk variabel electronic word of mouth, 0.846 untuk variabel promosi media sosial dan 0.884 untuk variabel minat beli. Menurut Bahri dan Zamzam (2015) jika jika Cronbach's Alpha $>0.60$ sampai dengan 0.80 maka dianggap baik atau reliabel serta dalam Cronbach's Alpha $>0.80$ sampai dengan 1.00 maka dianggap sangat baik atau reliabel.

Pengambilan keputusan dalam uji normalitas yaitu: 1). Jika nilai signifikan $>0.05$ maka data tersebut dinyatakan berdistribusi normal, 2). Jika nilai signifikansi $<0.05$ maka data tersebut dinyatakan tidak normal. Hasil uji normalitas menunjukkan bahwa hasil One Sample Kolmogorov-Smirnov Test menghasilkan asymptotic significance $\geq 0.05$ (0.403 $\geq 0.05$ ), maka dapat disimpulkan bahwa model regresi telah memenuhi asumsi kenormalan.

Untuk uji multikolinieritas diketahui bahwa nilai tolerance untuk variabel electronic word of mouth (X1) dan promosi media sosial (X2) adalah $0.868>0.10$ dengan nilai VIF $1.152<10$, sehingga mengacu pada dasar pengambilan keputusan dalam uji multikolinieritas tersebut dapat disimpulkan bahwa tidak terjadi gejala multikolinieritas dalam model regresi. Hasil uji heterokedastisitas dengan metode Glejser diketahui bahwa nilai signifikansi lebih besar dari 0.05 yaitu pada variabel electronic word of mouth $0.096>$ 0.05 dan nilai signifikansi variabel promosi media sosial $0.994>0.05$, dengan demikian dapat disimpulkan bahwa tidak terjadi masalah heterokedastisitas. Hasil uji koefisien determinasi $\left(\mathrm{R}^{2}\right)$ menjelaskan bahwa variabel electronic word of mouth dan promosi media sosial secara simultan bersama-sama mampu menjelaskan minat beli pelanggan pada
Customer Buying

Decision and

Promotional Mix 
Customer Buying Decision and

Promotional Mix

$\underline{90}$ produk fashion Eiger sebesar 32.8\% dan sisanya 67.2\% dijelaskan oleh sebab-sebab yang lain diluar variabel yang belum diteliti.

Dari hasil penelitian yang telah dilakukan oleh peneliti, electronic word of mouth dan promosi media sosial secara bersama-sama berpengaruh positif dan signifikan terhadap minat beli fashion Eiger. Hal ini dapat dilihat dari hasil uji Fhitung yang menunjukkan bahwa nilai Fhitung sebesar 21.466 nilai ini lebih besar dari $F_{\text {tabel }}$ yaitu 3.10 atau $F_{\text {hitung }}$ $21.466>\mathrm{F}_{\text {tabel }} 3.10$ dengan probabilitas 0.000 . Nilai probabilitas jauh lebih kecil dari 0.05 $(0.000<0.05)$ maka model regresi dapat digunakan untuk memprediksi minat beli atau dapat disimpulkan bahwa kedua variabel bebas electronic word of mouth dan promosi media sosial secara bersama-sama berpengaruh terhadap minat beli. Berdasarkan hasil dari uji t dapat diketahui bahwa variabel electronic word of mouth dan promosi media sosial berpengaruh positif dan signifikan terhadap minat beli masyarakat pada fashion Eiger di kota Bogor, dengan penjelasan sebagai berikut:

\section{Electronic word of mouth berpengaruh signifikan dan positif terhadap minat beli fashion Eiger}

Hasil analisis menunjukkan bahwa variabel electronic word of mouth memiliki thitung sebesar 2.125 dan nilai $t_{\text {tabel }}$ distribusi 5\% sebesar 1.66 sehingga dapat disimpulkan bahwa $t_{\text {hitung }}>t_{\text {tabel. }}$. Adapun nilai signifikansinya yaitu $0.036<0.05$ artinya variabel electronic word of mouth berpengaruh positif dan signifikan terhadap minat beli. Hasil ini sejalan dengan penelitian yang dilakukan oleh Hidayatullah dan Dirgantara (2018), Laksmi dan Oktafani (2016), Putri dan Sastika (2016), serta Cynthiadewi dan Hatammimi (2014) yang menyatakan bahwa electronic word of mouth mempengaruhi secara positif dan signifikan terhadap minat beli suatu barang. Hasil penelitian ini juga konsisten dengan penelitian yang dilakukan oleh Kumar dan Kudeshia (2017) yang menyatakan bahwa electronic word of mouth memiliki pengaruh positif terhadap minat beli dengan cara membentuk perilaku konsumen dan pada akhirnya menciptakan minat beli pada konsumen. Selain itu Jalivland (2012) mendukung hasil penelitian yang telah dilakukan, Jalivland (2012) menemukan bahwa electronic word of mouth memiliki peran untuk meningkatkan popularitas, dan konsumen dapat membaca rekomendasi produk secara online dan akan menciptakan minat beli yang kemungkinan besar dapat membentuk keputusan pembelian. Selain itu Cahyono et al. (2016) dalam penelitiannya mengungkapkan bahwa electronic word of mouth memiliki faktor - faktor yang mampu mempengaruhi minat beli yaitu Plafform Assistance, Expressing Positive Feelings, Economic Incentives, Helping the Company, dan Concern for Others. Menurut Sari (2012), Electronic word of mouth (eWOM) memiliki pengaruh yang positif terhadap minat beli konsumen. Hal ini menunjukkan bahwa semakin banyak electronic word of mouth (eWOM) yang diterima maka akan semakin besar pula pengaruhnya terhadap minat beli konsumen. Penerapan electronic word of mouth dalam media sosial dinilai jauh efektif karena dapat dijamah oleh masyarakat luas. Dengan menerapkan electronic word of mouth pada media sosial, para pelaku bisnis khususnya fashion dapat diuntungkan dengan low cost and high impact dari proses tersebut. Dengan berkembangnya pola pikir seseorang, konsumen akan menjadi lebih ekspresif dalam meyakinkan konsumen lainnya melalui opini dan pengalamannya. Media sosial juga dapat membantu pelaku bisnis untuk menampung keluhan pelanggan dan ketidakpuasan pelanggan secara langsung. (Cahyono et al. 2016). Dengan demikian dapat disimpulkan bahwa semakin tinggi penggunaan electronic word of mouth yang terjadi pada fashion Eiger maka akan semakin menarik minat pembelian oleh konsumen.

\section{Promosi media sosial berpengaruh signifikan dan positif terhadap minat beli fashion} Eiger

Hasil analisis variabel promosi media sosial menunjukkan bahwa promosi media sosial mempengaruhi minat beli masyarakat secara signifikan dan positif dengan nilai thitung sebesar 5.005 dan nilai pada t-tabel 5\% sebesar 1.66 maka nilai t-hitung $>$ t-tabel. Adapun nilai signifikansi yaitu $0.000<0.05$. Menurut Putranti dan Pradana (2015), para konsumen khususnya mahasiswa terlihat memberi persepsi yang baik terhadap kehadiran media sosial karena selain dapat digunakan untuk menjalin interaksi sosial dengan orang 
lain, juga dapat mencari berbagai produk yang dibutuhkan karena banyak penjual yang menggunakan media tersebut untuk menawarkan berbagai produk. Hanya saja untuk keinginan melakukan pembelian dari para konsumen untuk melakukan pembelian masih dipengaruhi oleh beberapa faktor, seperti ketersediaan produk yang dibutuhkan karena masih banyak penjual yang menawarkan produk secara fisik yaitu dengan membuka toko, sehingga konsumen akan lebih memilih melakukan pembelian di tempat tersebut apabila di media sosial tidak tersedia produk yang dibutuhkan. Hal ini berarti para pengguna sosial media harus lebih banyak mengajak para penjual yang belum menggunakan media sosial media untuk menggunakan media tersebut untuk menjual produknya sehingga kebutuhan konsumen lebih terpenuhi. Hal ini akan meningkatkan minat beli para konsumen terhadap berbagai produk yang dijual melalui sosial media.

Dengan adanya jalinan informasi dan komunikasi yang lebih tinggi diantara konsumen yang dilakukan melalui word of mouth maka akan lebih meningkatkan penggunaan sosial media untuk mencari produk yang diinformasikan atau direkomendasikan melalui word of mouth. Dengan ketersediaan produk di sosial media yang sesuai dengan kebutuhan maka akan menumbuhkan keinginan konsumen untuk melakukan pembelian. (Putranti dan Pradana, 2015). Hasil penelitian ini sesuai dengan penelitian yang dilakukan oleh Muslimawati et al. (2017), Andreani (2013), yang menyatakan bahwa promosi media sosial berpengaruh secara positif dan signifikan terhadap minat beli masyarakat. Semakin tinggi promosi media sosial maka akan semakin meningkatkan minat beli masyarakat, jejaring sosial juga dapat membuka peluang untuk media promosi secara efektif dan efisien (Putranti dan Pradana (2015).

\section{Electronic word of mouth dan promosi media sosial Berpengaruh secara simultan terhadap minat beli}

Berdasarkan hasil pengujian yang telah dilakukan diperoleh nilai $\mathrm{F}_{\text {hitung }}$ sebesar 21.466 , nilai ini lebih besar dari $F_{\text {tabel }}$ yaitu 3.10 atau $F_{\text {hitung }} 21.466>$ Ftabel 3.10 dengan probabilitas 0.000 . Nilai probabilitas jauh lebih kecil dari 0.05 sehingga dapat disimpulkan bahwa kedua variabel bebas electronic word of mouth dan promosi media sosial secara bersama-sama berpengaruh terhadap minat beli. Banyaknya informasi yang didapat oleh masyarakat melalui komentar-komentar yang ada di media sosial dapat membantu masyarakat dalam meningkatkan minat beli suatu produk, selain itu promosi yang dilakukan oleh perusahaan penjual produk menjadi salah satu faktor yang mendasari seseorang untuk melakukan pembelian. Hal ini sejalan dengan penelitian yang dilakukan oleh Azmar dan Laksamana (2018), Susanto dan Keni (2018). Azmar dan Laksamana (2018), dalam penelitiannya mengungkapkan bahwa munculnya daya tarik untuk membeli suatu produk terjadi setelah melihat informasi, adanya rasa ingin mengetahui lebih dalam mengenai produk yang ditawarkan dengan cara menghubungi kontak informasi, adanya melakukan interaksi memberikan komnetar pada kolom komen dan adanya usaha dari seseorang yang mengajak untuk mem-follows, seseorang yang membagikan informasi dengan orang lain secara online maupun komunikasi dari mulut ke mulut terhadap informasi yang diposting pada akun resmi sosial media. Sementara itu Susanto dan Keni (2018) menyampaikan bahwa dalam promosi di media sosial dan electronic word of mouth harus memperhatikan ulasan-ulasan yang diberikan oleh pelanggan atau calon pelanggan. Ullasan positif dari calon pelanggan ataupun pelanggan seringkali menjadi bahan pertimbangan bagi calon pelanggan lainnya sebelum memutuskan untuk membeli suatu produk atau tidak. Apabila ulasan yang didapat melalui electronic word of mouth dari calon pelanggan atau pelanggan mengenai produk tertentu yang bersifat positif maka akan meningkatkan minat beli calon pelanggan baru.

\section{PENUTUP}

Variabel dalam penelitian ini adalah electronic word of mouth, promosi media sosial dan minat beli dengan tujuan untuk mengetahui pengaruh dari variabel electronic dan
Customer Buying

Decision and

Promotional Mix 
Customer Buying Decision and Promotional Mix promosi media sosial baik secara simultan maupun parsial. Berdasarkan hasil analisis dengan menggunakan SPSS 22 dapat disimpulkan bahwa:

1. Electronic word of mouth memiliki pengaruh yang positif dan signifikan terhadap minat beli fashion Eiger di kota Bogor, semakin banyak masyarakat yang memberikan informasi melalui media sosial maka akan semakin meningkatkan minat masyarakat untuk membeli brand fashion Eiger.

2. Promosi media sosial memiliki pengaruh yang positif dan signifikan terhadap minat beli brand fashion Eiger di kota Bogor. Semakin banyak promosi yang dilakukan oleh brand fashion Eiger di media sosial maka akan meningkatkan minat beli masyarakat di kota Bogor

3. Electronic word of mouth dan promosi media sosial memiliki pengaruh yang signifikan dan positif terhadap minat beli masyarakat secara bersama-sama, sehingga dapat disimpulkan bahwa semakin banyaknya masyarakat mengenal brand fashion Eiger maka akan melalui eWOM dan promosi di media sosial maka akan meningkatkan minat beli masyarakat.

\section{DAFTAR PUSTAKA}

[1] Binangkitsari, L., 2018. The Influence of Brand Equity Elements on Purchase Decision and Its Imlication on Customer Loyalty.

[2] Gendalasari, G.G. and Triandi, T., 2018. Potret Kinerja UMKM Sepatu Di Bogor Dalam Berkompetisi Pada Perekonomian Di Indonesia. Jurnal Ilmiah Manajemen Kesatuan, 6(2), pp.102-108.

[3] Hidayat, L., Muktiadji, N. and Supriadi, Y., 2019. Pengaruh Pengetahuan Investasi Terhadap Minat Mahasiswa Berinvestasi Di Galeri Investasi Perguruan Tinggi. JASPT (Jurnal Analisis Sistem Pendidikan Tinggi Indonesia), 3(2), pp.63-70.

[4] Iriyadi, I., 2019. Prevention of Earnings Management through Audit Committee and Audit Quality in the Award-Winning and Non-Winning Companies. Journal of Accounting Research, Organization and Economics, 2(2), pp.155-169.

[5] Keren, K. and Sulistiono, S., 2019. Pengaruh Motivasi, Budaya, dan Sikap Konsumen Terhadap Keputusan Pembelian Produk Indomie. Jurnal Ilmiah Manajemen Kesatuan, 7(3), pp.319-324.

[6] Munawar, A., Syarif, R. and Morita, M., 2019. Persepsi Mahasiswa Atas Galeri Investasi Perguruan Tinggi dan Pengaruhnya Terhadap Minat Berinvestasi. JAS-PT (Jurnal Analisis Sistem Pendidikan Tinggi Indonesia), 3(2), pp.89-96.

[7] Nuraini, A., Gendalasari, G.G. and Sastra, H., 2017. Studi Peningkatan Pertumbuhan dan Nilai Perusahaan Sektor Perkebunan Melalui Analisis Kebijakan Dividend an Profitabilitas. Jurnal Ilmiah Manajemen Kesatuan, 5(2), pp.074-079.

[8] Purba, J.H.V., Ratodi, M., Mulyana, M., Wahyoedi, S., Andriana, R., Shankar, K. and Nguyen, P.T., 2019. Prediction Model in Medical Science and Health Care. International Journal of Engineering and Advanced Technology, 8, pp.815-818.

[9] Setiawan, B., Panduwangi, M. and Sumintono, B., 2018. A Rasch analysis of the community's preference for different attributes of Islamic banks in Indonesia. International Journal of Social Economics.

[10] Wibowo, W. and Mekaniwati, A., 2020. Pengaruh Struktur Modal dan Kemampulabaan Terhadap Return Saham Perusahaan Properti dan Real Estate Yang Terdaftar di BEI Tahun 2013-2015. Jurnal Ilmiah Manajemen Kesatuan, 8(1), pp.19-28.

[11] Zuhdi, S., Rainanto, B.H. and Apriyani, D., 2020, May. Analysis of Co-Branding Strategy to Improve Company's Competitive Power (Case Study on Walls Selection Oreo). In 2nd International Seminar on Business, Economics, Social Science and Technology (ISBEST 2019) (pp. 146-149). Atlantis Press.

[12] Andreani, Grace. (2013). Pengaruh Promosi Melalui Media Sosial terhadap Minat Beli Samsung Berbasis Android pada Mahasiswa Universitas Sumatera Utara. 
Skripsi. Program Studi Manajemen Departemen Manajemen Fakultas Ekonomi Universitas Sumatera Utara. [Tidak Dipublikasikan].

[13] Arief, Giri Maulana dan Heppy Millianyani. (2015). Pengaruh Social Media Marketing Melalui Instagram Terhadap Minat Beli Konsumen Sugar Tribe. Fakultas Ekonomi dan Bisnis Universitas Telkom.

[14] Assael H. (2001). Consumers Behavior and Marketing Action, Edisi 3, Kent Publishing Company, Boston Massachusset, AS.

[15] Azmar dan Laksamana, Patria. (2018). Pengaruh Sosial Media Promotion dan Electronic Word of Mouth terhadap Keputusan Pemilihan pada Perguruan Tinggi. Jurnal Riset Perbankan Manajemen dan Akuntansi, 2 (2): 123-13

[16] Balea, Judith. (2016). The Latest Stats In Web And Mobile In Indonesia (Infographic). https://www.techinasia.com diakses tanggal 29 Oktober 2016 dari https://www.techinasia.com/indonesia-web-mobile-statistics-we-are-social.

[17] Cahyono, Firman Dwi. Kusumawati, Andraini. Kumadji, Srikandi. (2016). Analisis Faktor - Faktor Pembentuk Electronic Word of Mouth (eWOM) dan Pengaruhnya terhadap Minat Beli. Jurnal Administrasi Bisnis, 37 (1): 148-157

[18] Christy M,K,C., dan Lee Matthew, K,O. (2010). "What Drives Consumers to Spread Electronic Word of Mouth in Online Consumer-Opinion Platforms". Article Of Decision Support System.

[19] Cong, Y., \& Zheng, Y. Q. (2017). A Literature Review of the Influence of Electronic Wordof-Mouth on Consumer Purchase Intention. Open Journal of Business and Management, 5, 543 - 549.

[20] Cynthiadewi, P, R dan Hatammimi, J. (2014). The Influence of Electronic Word of Mouth Toward Brand Image and Purchase Intention on $13^{\text {th }}$ Shoes. International Conference on Economics, Education and Humanities (ICEEH'14). p: 66-70

[21] Durianto, Darmadi. (2003). Inovasi Pasar dengan Iklan yang Efektif: Strategi, Program, dan Teknik Pengukuran. Jakarta: PT. Gramedia Pustaka Utama

[22] Ellya. (2015). Promosi Wisata Lebih Cepat Lewat Sosmed dan Media Sosial. http://beritajateng.net diakses tanggal 11 November 2016 pada jam 15.46 dari http://beritajateng.net/promosi-wisata-lebih-cepat-lewat-sosmed-dan-mediasosial/.

[23] Ghozali, I. (2005). Aplikasi Analisis Multivariate dengan Program SPSS Edisi Ketiga. Semarang: Badan Penerbit Universitas Diponegoro.

[24] Goyette, I., Richard L, Bergeron J, \& Marticotte F. (2010). e-WOM Scale: Word of Mouth Measurement Scale for e-services Context. Canadian Journal of Administrative Sciences/Revue Canadianne des Sciences de l'Administration. 27 (1): $5-23$

[25] Hidayatullah, M, R. Dirgantara I, M, B. (2018). Pengaruh Electronic Word of Mouth, Dukungan Selebritas, dan Pemasaran Media Sosial terhadap Minat Beli dengan Brand Image sebagai Variabel Intervening. Diponegoro Journal of Management. 7 (4): 1-10. ISSN (Online): 2337-3792.

[26] Jalilvand dan Samiei (2012). The effect of word-of-mouth on brand image and purchase intention: An empirical study in the automobile industry in Iran. Marketing Intelligence \& Planning Vol 30 No.4.

[27] Kholiq, A. A. (2019). Analisis SWOT dalam Menentukan Strategi Pemasaran Produk Eiger (Studi pada Store Eiger Jalan Kaliurang). Skripsi. Program Studi Manajemen. Sekolah Tinggi Ilmu Ekonomi Widya Wiwaha Yogyakarta.

[28] Kotler and Keller. (2016). Marketing Management. Pearson: Prentice hall

[29] Kshetri, Anita and Bidyanand Jha. (2016). "Online Purchase Intention : A Study of Automobile Sector in India”. Rev. Integr. Bus. Econ. Res. Vol. 5 No.3, p.35-59.

[30] Kumar, Amresh., Kudeshia Chetna (2017) Social Ewom: Does It Affect The Brand Attitude And Purchase Intention Of Brands?. Management Research Review Vol. 40 No. 3
Customer Buying Decision and Promotional Mix 
Customer Buying

Decision and

Promotional Mix

94
[31] Laksmi, Aditya Ayu. Oktafani, Farah. (2016). Pengaruh Electronic Word of Mouth (eWOM) terhadap Minat Beli Followers Instagram pada Warung Upnormal. Jurnal Computech \& Bisnis, 10 (2): 78-88.

[32] Madahi, Abdolrazagh dan Inda Sukati. (2012). "The Effect of External Factors on Purchase Intention Amongst Young Generation in Malaysia". International Business Research. Vol. 5 No.8, p. 153-159.

[33] Maoyan et al. (2014). "Consumer Purchase Intention Research Based on Social Media Marketing”. International Journal of Business and Social Science. Vol. 5 No.10 (1), p.92-97.

[34] Muslimawati, C. Sunarto. Wardani, D, K. (2017). Pengaruh Promosi melalui Media Sosial dan Kesadaran Merek terhadap Minat Beli Air Minum dalam Kemasan dengan Merek Aqua pada Mahasiswa Pendidikan Ekonomi FKIP UNS. Jurnal Pendidikan Bisnis dan Ekonomi. 3 (2): 1-19.

[35] Namiraniyah BRA Koes. (2015). Akun Facebook sebagai Sarana Marketing Public Relations PT. Eigerindo Multi Produk Industri. Skripsi. Program Studi Ilmu Komunikasi Fakultas Ilmu Komunikasi Universitas Prof. DR. Moestopo (Beragama). Jakarta

[36] Nurgiyantoro, Singgih. (2014). Pengaruh Strategi Promosi Melalui Media Sosial terhadap Keputusan Pembelian Garskin yang Dimediasi Word of Mouth Marketing (Studi pada Konsumen Produk Garskin Merek SayHello di Kota Yogyakarta). Skripsi. Manajemen Fakultas Ekonomi Universitas negeri Yogyakarta. Yogyakarta.

[37] Prabowo I, J, K, G. (2016). Pengaruh Citra Merek, Kualitas Produk, Persepsi Harga, dan Word of Mouth terhadap Minat Beli. Skripsi. Program Studi Manajemen Jurusan Manajemen Fakultas Ekonomi Universitas Negeri Yogyakarta.

[38] Putranti, Ratnawati Dwi. Pradana, FX Denny. (2015). Electronic of Word of Mouth (E-WOM), Kepuasan Konsumen dan Pengaruh Langsung dan Tak Langsung Terhadap Minat Beli Konsumen (Studi Kasus Pada Mahasiswa Untag di Semarang). Jurnal Media Ekonomi dan Manajemen. 30 (1): 101-113.

[39] Putri, Harnita dan Sastika, Widya. (2016). Pengaruh Electronic Word of Mouth (EWOM) Melalui Twitter Terhadap Minat Beli Konsumen pada Steak Ranjang Bandung. Prosiding SNapp2016 Sosial, Ekonomi, dan Humaniora, 6 (1): 637-643

[40] Rimayanti, A, A. (2018). Pengaruh Kualitas Produk dan Citra Merek terhadap Loyalitas Pelanggan pada Tas Eiger di Samarinda. eJournal Administrasi Bisnis. 6 (4): 1745-1759. ISSN 2355-5408, ejournal.adbisnis.fisip-unmul.ac.id

[41] Rofian, M. (2016). Analisis Pengaruh Word of Mouth, Persepsi Kualitas, dan Harga terhadap Keputusan Pembelian Produk Eiger. Paper. Corpus ID: 191669109

[42] Sari RDK, Astuti SRT. (2012). Analisis Pengaruh Kualitas Produk, Persepsi Harga, Dan Word Of Mouth Communication Terhadap Keputusan Pembelian Mebel Pada CV.Mega Jaya Mebel Semarang. Skripsi

[43] Sa'ait, N., Kanyan, A., Nazrin, M. F. (2016). The Effect of E-WOM on Customer Purchase Intention. International Academic Research Journal of Social Science. 2 (1): 73 80.

[44] Setiawan MR, Rachmawati I. (2019). Strategi Digital Content Marketing Eiger Melalui Media Sosial Instagram. Prosiding Manajemen Komunikasi. 5 (2): 625-632

[45] Susanto, W, K, dan Keni. (2018). Pengaruh Social Network Marketing (SNM), dan Electronic Word of Mouth (EWOM) Terhadap Minat Beli Pelanggan. Jurnal Manajemen Bisnis dan Kewirausahaan, 2 (6): 68-73.

[46] Tommi Wijaya, Eristia Lidia Paramita. (2014). "Pengaruh Electronic Word of Mouth (eWOM) Terhadap Keputusan Pembelian Kamera DSLR", Seminar Nasional dan Call for Paper (Sancall 2014), Universitas Kristen Satya Wacana.

[47] Van Vliet, Vincent. (2014). AIDA Model. http://www.toolshero.com diakses pada tanggal 4 November 2019 pada jam 21.15 dari http://www.toolshero.com/marketing/aidamodel/ 